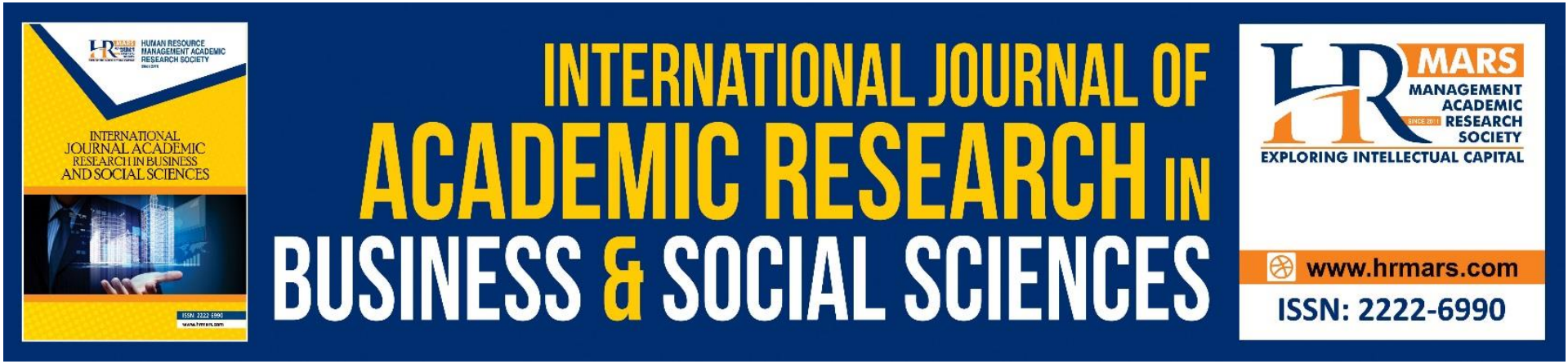

\title{
Synergy of Strategy in Producing Research Quantities and Publications
}

\section{Akli Ahmad \& Mohamad Ridhauddin bin Mohd Salleh}

To Link this Article: http://dx.doi.org/10.6007/IJARBSS/v11-i12/11923 DOI:10.6007/IJARBSS/v11-i12/11923

Received: 16 October 2021, Revised: 20 November 2021, Accepted: 30 November 2021

Published Online: 26 December 2021

In-Text Citation: (Ahmad \& Salleh, 2021)

To Cite this Article: Ahmad, A., \& Salleh, M. R. bin M. (2021). Synergy of Strategy in Producing Research Quantities and Publications. International Journal of Academic Research in Business and Social Sciences, 11(12), 1987-1994.

\section{Copyright: (c) 2021 The Author(s)}

Published by Human Resource Management Academic Research Society (www.hrmars.com)

This article is published under the Creative Commons Attribution (CC BY 4.0) license. Anyone may reproduce, distribute, translate and create derivative works of this article (for both commercial and non0-commercial purposes), subject to full attribution to the original publication and authors. The full terms of this license may be seen at: http://creativecommons.org/licences/by/4.0/legalcode

Vol. 11, No. 12, 2021, Pg. 1987- 1994

Full Terms \& Conditions of access and use can be found at http://hrmars.com/index.php/pages/detail/publication-ethics 


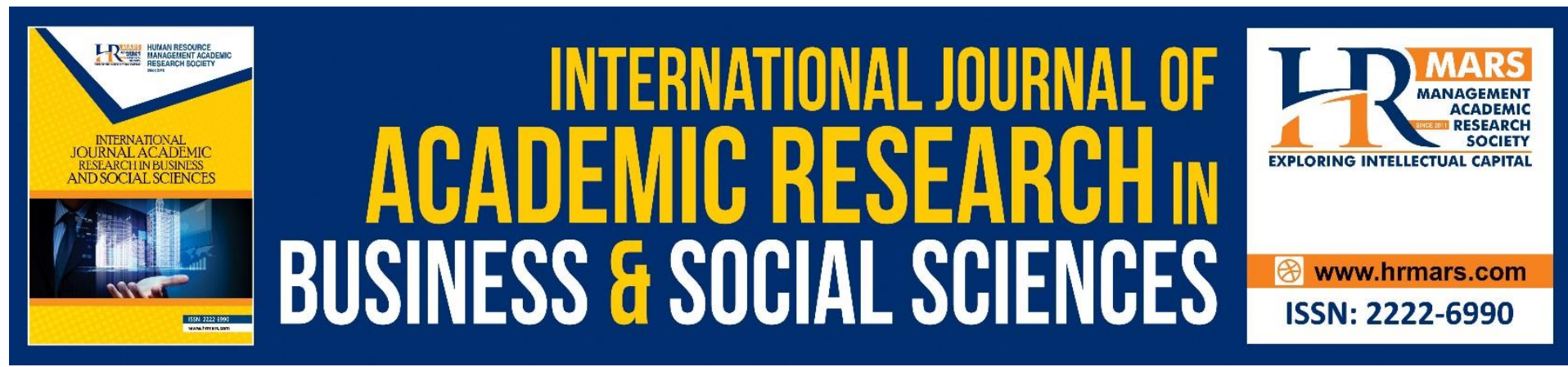

\title{
Synergy of Strategy in Producing Research Quantities and Publications
}

\author{
Akli Ahmad ${ }^{1} \&$ Mohamad Ridhauddin bin Mohd Salleh² \\ ${ }^{1}$ Dean, Kulliyyah Syariah, Universiti Islam Antarabangsa Sultan Abdul Halim Mu'adzam Shah \\ (UniSHAMS), ${ }^{2}$ Lecturer, Kulliyyah Syariah, Universiti Islam Antarabangsa Sultan Abdul Halim \\ Mu'adzam Shah (UniSHAMS) \\ Email: akliahmad@unishams.edu.my¹, ridhauddin.salleh@unishams.edu.my²
}

\begin{abstract}
Research is a pillar of knowledge activity that is the basis for the progress and development of a human civilization. While synergy in research has been given priority by Islam through the verses of the Quran which means; "And help each other in goodness" (al-Maidah , 2) and the hadith of the Prophet SAW which means: "The power of God with a group of people" (Sunan al-Tirmidzi, 1998). Synergy is the core to quality, quantity, and human excellence in developing worldly civilization and hereafter (ukhrawi) success. In the academic world, research needs synergy and strategy in tandem to add value to the quality of a study. Among the strategies in research is the quantity that plays a role in increasing the excellence of civilization, especially in the academic field. Research synergies can develop ideas that have been jointly released more quickly, diverse, and efficiently. Although many early scholars were recorded as renowned researchers with thousands of volumes of excellent manuscript writing individually, but their research has been updated by academics in groups in terms of editing and reviewing for the purpose of quality publication. Group research strategy is very good in terms of generating ideas, discussion of topics and distribution of the scope of assignments in order to produce quality research. In addition, the diversity of writing fields also needs to be strengthened by each member of the research team even if the person has a specific and dedicated field of specialization. A variety of types of writing, such as inventions, reviews, translations, descriptions, summaries and so on are able to add to the quantity of research. Synergy between humans and technology is necessary and the mastery of social media by some members of the research team in seeking information can identify the information obtained is up to date and not repetitive. The synergy in research inculcating new ideas will be more efficient to assess the authenticity of ideas so as not to be seen as stealing information or being an academic predator. Research produced in groups will cause an organization and country to be more recognized and well respected, especially in the rating of the competent bodies on academic organizations, where the quality of research and quantity are highly emphasized to make it a superior academic organization. In the Malaysian higher education system, the quantity and quality of research is a equivalent requirement for the rating of the academic institution. Indeed, research is a symbol of the quality of a country's
\end{abstract}


civilization. Hopefully, this study will be published for the purpose of being expanded to relevant parties to advance the academic world.

Keywords: Research, Publication, Strategy, Synergy, Rating, Civilization

\section{The Importance of Synergy in Research and Publication Introduction: Synergy is an Element of Excellence}

The word "synergy" comes from English word and has been used in Malay community for a long time. It has a very strong meaning between understanding and practice. According to Deardorff and Williams (2006) is a process of interaction between two or more individuals or institutions to produce something optimal that cannot be produced individually. In many aspects of life, human beings have proven their success in every planning carried out when it is done in groups. Outstanding success in this world and the hereafter is largely contributed by teamwork and intertwined with various facilities, utilities, technology, and infrastructure. This is as the hadith of the Prophet SAW which means: " Work, indeed everything is created for the convenience of all human beings" (Al-Mufrad, 1989). This hadith emphasizes on the importance of living a career by intertwining with everything that is around us for the purpose of facilitating work and quality.

\section{Quantity And Quality}

The quality and quantity of research are the two main things in academic activities in adding value to knowledge, writers, communities, and countries.

Synergy in research is given priority by Islam to inculcate a good value of nations in building human civilizations. The nature of knowledge is alive and always relevant. It coincides with the principle that says the door of ijtihad will not be closed. Starting with the knowledge of faith, sharia, morality, worldly and hereafter (ukhrawi) all adhere to the idea of hereditary ijtihad and will continue to remain until the end of the world (Dr Ali Jumaah). The need of ijtihad is fundamental and in requires for continuous study and research. Therefore, the mujtahid scholars who are experts in their respective fields strive with the ability of knowledge, thinking skills, strength of methods and arguments for ijtihad. Therefore, at all times and places, fatwas and views are issued on any issues that arise as a solution to those issues. Allah SWT says (which means) "For every soul the reward is the rate of his deeds, and (so is) the bad reward of the rate of his deeds" (Al-Baqarah, 286). The method of fiqh mentions a theory that means: "The reward of something is based on the quantity of deeds done ( كَثْرَة الثَََّابِ كَثْرَة الْفِعْلِ the hadith of the Prophet SAW which means: "The power of Allah with a group of people"

\section{The Importance of Synergy in Research and Publication}

\section{Synergy is a Religious Demand}

Synergy is group work or collaboration with any party to perform a similar task in the form of ideas, energy, capital and other matters. In this case, Islam places great emphasis on synergistic work in many fields including worship, muamalat, munakahat (marriage) and sharia criminal code. This synergistic claim in Islam can also be linked to the field of academic research and publication. Certainly, this matter becomes necessity that will invite maslahah (benefit) to mankind as a whole. This has been stated in the Qur'an which means: "And every affair of theirs is in the concept of deliberation among themselves" and the story of Prophet Musa (as) which means: "That is Harun my brother. Strengthen my position with his support. 
And make him responsible in my affairs" (Sunan al-Tirmidzi, 1975). Nobody can deny that group work has strong spiritual and physical energy and blessings from Allah SWT. Thus, the work becomes easy and smooth. Therefore, research carried out in groups has its own strength and will be blessed by Allah SWT. Finally, the results of this research. will produce a thoughtful resolution and accepted by Allah and human. Thus, the findings of this study will be able to provide benefits to the public.

\section{Profound Idea Sharing}

Quality research requires thoughtful and fresh-breathed ideas. Thus, research conducted collaboratively by several researchers will be more efficient to produce new ideas that are more thoughtful. Because the collective discussion will usually be discussed in a more indepth and thorough discussion with each will present facts, views, evidence and authoritative sources of references. With a diverse collection of information and many references as well as the ideas of members of the research team will certainly produce quality, high-impact research with thoughtful and problematic ideas. In the aspect of knowledge, the opinion of the majority of scholars is usually stronger than the opinion of individuals. This coincides with the words of the Prophet SAW which means: "It is obligatory for you all to be with the majority group". The words of the Prophet SAW in another hadith which means: "Two people are better than one, three people are better than two people, and four people are better than three people, it is obligatory upon you with a group of people; because they will not conspire on the wrong thing

\section{Scope of Duties of The Research Group}

Group research will speed up the process of completing the study in a given period of time. This is because group synergy can conduct research in the form of distribution of task scope to each member of the research group involved. With the distribution of tasks to researchers, each task becomes lighter and simplifies the work involving research especially when the study is a field study that requires the members of the group that conducts the survey the same expert consultation, interviews with industry and so on. There is a Malay proverb indicates that situation which says "lemah menapis condong menopang ".

\section{Authenticity and Validity of The Research Content}

Group research will also make the information stated stronger and more thorough as it is produced by research groups that specialize in different fields. Synergy in the study provides more assurance on the quality of a study. The Prophet SAW said which means: "My ummah will not conspire in mistake (Al-Minhaj Syarh Sahih Muslim bin Hajjaj, 1972)". Synergy can usually avoid agreement in fraud or lies in conveying information. In fact, it is more believed to be true or genuine in its news including the studies conducted.

\section{Synergy between Humans, Technology and Media}

Research and publication in any era, it requires a combination of human, technology and current media so that the research conducted is more advanced and wider access to information across the world easily quickly accurate and true. The words of the Prophet SAW which means: "Work, indeed everything is created for the convenience of all human beings". This is part of what has been stated in the Qur'an that all of God's creations on earth are for the convenience of mankind as a whole. 


\section{Synergy between Research and Funding}

Research with a variety of methods requires funds and finance to complete a study. Certainly, a group of researchers who will use a variety of mediums to perfect their research need a strong financial support. Not to mention the studies that involve the use of laboratories, equipment, technology, expert services in related fields and so on. Researchers may not be able to provide funding on their own. Perhaps there are large companies that need to innovate research and study to advance and expand their business lines. They therefore need to issue funds to cover the need for the study. The benefits of the study shall return to both parties simultaneously. Even the institution will also get the benefits at once. Even in the field of social sciences, it sometimes requires large funds for research purposes. The Malaysian government has issued a decision to increase research funds, including 50 percent of which will be channeled to the Experimental Research Fund (DPE). The Prime Minister said 50 per cent of the government's research funds would be provided for experimental research that has the potential to be commercialized. Following this, Prime Minister Datuk Seri Ismail Sabri announced that the government had approved the establishment of a one -stop center for commercialization and technology transfer and the Nano Malaysia Energy Storage Technology Program. Initiative (NESTI). In order to coordinate the activities of the Research, Development, Commercialization, and Innovation (R \& D \& C \& I) Fund and ensure that it is in line with national priorities, a Research Management Unit (RMU) has been established. "The role of RMU is to reduce duplication of functions, strengthen cooperation between industry, academia and government in various fields, as well as increase efficiency in the use of existing resources ". In addition, alternative funding sources including venture capital, international financing and endowment funds will be enhanced. He added that in 2025, the percentage of gross R\&D expenditure to GDP is expected to reach 2.5 percent, compared to only 1.0 percent in 2020. This is a large amount of funds allocated by the government for research purposes that have a high impact on the progress of the country. In addition, there are various private and corporate institutions that also provide their own research funds.

\section{Synergy between Institutional Researchers and Authorities}

Every research and publication definitely require recognition and certification so that every study conducted is valuable and gives added value to researchers and institutions whether Public Institution of Higher Learning (IPTA) or Private Institution of Higher Learning (IPTS). Therefore, cooperation between researchers, institutions and the authorities must always be strengthened because good relations between the parties involved will facilitate the application for certification and evaluation from the authorities involving higher education departments, Malaysian Qualifications Agency (MQA) and relevant ministries. This is necessary because it provides added value and recognition by the relevant parties for the continuity and academic progress of a school.

\section{More Efficient Research Quantities}

Synergy in research will undoubtedly be a key instrument to the production of research quantity as it goes through a process of group research that is full of methods and distribution of tasks. Quantity also plays an important role in various matters including the rating of an academic institution such as university colleges and universities, where the MQA in conducting audit work on institutions of higher learning registered under the ministry will look at several things including the quantity of research produced by the lecturer. And it is considered as measurement for the academic progress of a Public Institution of Higher 
Learning (IPTA) and a Private Institution of Higher Learning (IPTS). Therefore, it will be a landmark for the success of an IPT. Among others, it will be an attraction for students to continue their studies at the IPT. And this will have a huge impact on the revenue and finances of HEls as well as the progress of research indirectly. synergy between research and funders is necessary because research also requires relatively large funding.

\section{Synergy between Research, Presentation, Copyright and Publication}

Research is the basis for the dissemination of knowledge among scientists, institutions, industry, funders, and government. Therefore, each research needs an advanced process so that the results of the study have a high impact by way of the presentation of the study to experts in the field and also the funders. This will provide an opportunity for research to get comments, reviews, additional ideas, and suggestions from relevant parties. Certainly, this process will make a study have a high academic value as well as its superior impact. Furthermore, the process of obtaining copyright must be done so that the results of the study are not stolen by irresponsible parties especially in this age of technological advancement, it will make it easier for them to commit criminal acts in academia. Criminals in this category are normally labeled as journal predators or "bogus" or scammer and so on. Malaysia is now referred to by some people as a paradise for predators. Therefore, the publication process needs to be done so that it can be taken advantage of by interested parties and institutions. Thus, the synergy between research, presentation, publication, and registration of copyright is a complete package for each study so that it achieves maximum benefits to religion, race and country. Even Islam recognizes copyright as intellectual property.

\section{Synergy between Strategy and Diversity of Studies}

Synergies in research can be seen to be more efficient and advanced when combined with a variety of writing and research techniques. There are various methods can be used in writing either traditional or contemporary. The same title can be processed into various forms of writing that can be considered as different ideas or different concept paper. Thus, it contributes to various evaluations and scoring as well as increasing the form of publications and findings, that benefit various backgrounds and levels of society, whether experts,

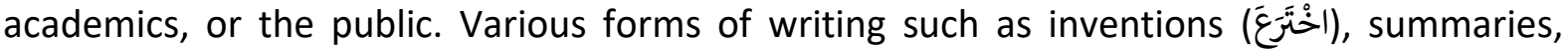
lectures, comments, translations, comparisons, editing, gatherings of scattered information into one book (or chapters in a book) (Ibn Khaldun, Ibn Muqarri, Ibn Hazm).

\section{Establishing a Research Title Bank}

The synergy of research among academics will spark diverse and interesting ideas to create a bank of research-related topics in the future. It is considered as ijthad because academic research is centered on knowledge which is a religious demand. This is so because it will give maslahah (benefit) to the religion of the nation and country. The existence of this research title bank will facilitate the research group or other parties to conduct further research. the existence of this bank can also trigger new innovative ideas to produce related or extended titles.

\section{Conclusion}

We can conclude from this paper the following conclusions:

1. Synergy means cooperation or combination of expertise either among human or human and non-humans. 
2. Synergy is a natural need in human life to facilitate every human affair.

3. Synergy is a religious activity that involves all aspects of life including in academic writing and research.

4. Synergy is an effective research strategy in terms of producing high-quality research in a significant quantity because it involves a lot of mental and physical energy and is supported by all the available facilities related to technology and utilities that speed up the research process.

5. Synergy in research can be seen from the point of view of interweaving related to the processing of the same content into various forms of writing and research. This will provide added value in terms of assessment and scoring by the authorities.

6. Synergy between researchers and funders is a main pillar to studies and research that requires capital. Not to mention studies that involve field, technical, laboratory and interview studies. For this purpose, it is recommended to industry and government to provide research funds appropriate to the type of study to produce quality and high impact studies.

7. Recognition of every research conducted by researchers is necessary to encourage academics to engage more aggressively in research, especially high -impact research.

8. The government through its policies is generally responsible for building the progress and development of a successful nation -state through high -impact research because knowledge is the core of success for every field ventured into.

\section{References}

Al-Adab al-Mufrad. (1989). Muhammad bin Ismail bin Ibrahim bin al-Mughirah al-Bukhari (demise $256 \mathrm{H}$ ) commented by Muhammad Fuad 'Abdul Baqi. Beirut: Dar al-Basyair alIslamiah.

Al-Furuq. (t.t). Abu al- 'Abbas Syihabuddin Ahmad bin Idris bin 'Abdul Rahman al-Maliki alQarafi (demise 684). 'Alam al-Kitab. Jil. 2 Hal. 133

Al-Asybah, W. Al-Nazhair. (1990). 'Abdul Rahman bin Abu Bakar Jalaluddin al-Suyuthi (demise 911H). Beirut: Dar al-Kutub al- 'Ilmiah.

al-Minhaj Syarh Sahih Muslim bin Hajjaj. (1972). Abu Zakaria Muhyiddin Yahya bin Syaraf alNawawi (demise 676H). Beirut: Dar Ihya al-Turath al- 'Arabi.

Sunan, al-Tirmidzi. (1998). Muhammad bin 'Isa bin Saurah bin Musa bin Dhahhak al-Tirmidzi (demise279H) commented by oleh Basyar 'Awwad Ma'ruf. Beirut: Dar al-Gharb alIslami. Jil. 4 Hal. 36 No. 2166

Synergy leadership in quantum organizations. Deardorff. (2006). D. S., \& Williams, G. New York: Fesserdorff Consultants.

Majma' al-Zawaid wa Manba' al-Fawaid. (1994). Abu al-Hasan Nurudin 'Ali bin Abu Bakar bin Sulaiman al-Haithami (demise $807 \mathrm{H}$ ) commented by Husamuddin al-Qudsi. Kaherah: Maktabah al-Qudsi.

Musnad, Al-I. A. bin H. (2001). Abu Abdillah Ahmad bin Hanbal bin Hilal bin Asad al- Syaibani (demise $241 \mathrm{H}$ ) commented by oleh Syu'aib al-Arnaouth, Adil Mursyid and others under the supervision of Abdullah bin Abdul Muhsin al-Turki. Beirut: Muassasah al-Risalah.

Nihayatu, Al-S. S. M. Al-W. (1999). 'Abdul Rahim bin al-Hasan bin 'Ali al-Isnawi al-Syafie (demise 772H). Beirut: Dar al-Kutub al- 'Ilmiah.

Sahih Bukhari. Muhammad bin Ismail Abu Abdullah al-Bukhari. Commented by Muhammad Zahir bin Nasir al-Nasir. Dar Thuq al-Najah. 
Silsilatu, Al-A., Al-Dha'ifah, Wa Al-M.'Ah Wa A. Al-S. fi Al-U. (1992). Abu Abdul Rahman Muhammad Nasiruddin al-Bani (demise 1420H). Riyadh: Dar al-Ma'arif.

Silsilatu, al-Ahadith al-Sahihah wa Syai'un min Fiqhiha wa Fawaidiha. (1995-2002). Abu 'Abdul Rahman Muhammad Nasiruddin Albani (demise 1420H). Riyadh: Maktabah alMa'arif.

Al-Tirmidzi, S. (1975). Muhammad bin 'Isa bin Saurah bin Musa bin al-Dhahhak al-Tirmidzi (demise $279 \mathrm{H}$ ) commented by Ahmad Muhammad Syakir, Muhammad Fuad 'Abdul Baqi and Ibrahim 'Athwah. Egypt: Mustafa al-Babiy al-Halabi.

'Umdatu al-Qari Syarh Sahih al-Bukhari. (t,t). Abu Muhammad Mahmud bin Ahmad bin Musa bin Ahmad bin Husain al-Ghitabi al-Hanafi Badruddin al- 'Aini (demise 855H). Beirut: Dar Ihya' al-Turath al- 'Arabi. Jil. 2 Hal. 52 No. 72 \& Jil. 16 Hal. 164.

\section{Websites}

https://malaysiagazette.com/2020/11/04/jurnal-predator-musuh-nombor-satukesarjanaan/bertarikh 8 Disember 2021.

https://orangkata.my/isu-semasa/malaysia-dikatakan-syurga-predatory-journals-kamijelaskan-keadaan-yang-berlaku/8 Disember 2021.

https://aliftaa.jo/nofatwa3501/16.5.2019.

https://www.elbalad.news/3491730

http://afaqattaiseer.net/vb/showthread.php?t=37993 